\title{
Demenciával élők életminőségének javítása demenciabarát szemléletü foglalkoztatásokkal
}

\author{
Kosztáné Hadházi Tünde - Pék Győző \\ KosZTÁNÉ HADHÁZI TÜNDE: DMJV Város Szociális Szolgálat - tunde.hadhazi@gmail.com \\ PÉK GYőző: Debreceni Egyetem BTK Pszichológiai Intézet - viktorbaker55@gmail.com
}

\begin{abstract}
ABSZTRAKT Tanulmányunk célja, hogy a demenciában szenvedők számára kialakított strukturált foglalkoztatás gyakorlatának legfontosabb szempontjait bemutassa. A demencia szindróma fokozódó gyakorisága egyre növekvő terhet jelent a társadalom számára. A háttérintézményekre, a tehermentesítő szolgáltatásokra és a családi gondozókra nagy nyomás nehezedik a demenciával élők mindennapi gondozása, ellátása folyamán. A foglalkoztatás segíti a betegeket a kognitív funkciók müködésének lehetséges fenntartásában a fokozatos romlás ellensúlyozásával azoknál a betegeknél, akik a neurodegenerativ természetű Alzheimer-kórban szenvednek. Maga a betegség nem gyógyítható, de a folyamata befolyásolható. A szocioterápiás keretben nyújtott speciális foglalkoztatás hozzájárulhat a betegek kognitiv funkcióinak, kommunikációjának, interaktivitásának fenntartásához. Nagyon fontosak azok a törekvések, amelyek a demenciával élök méltóságának és önbecsülésének fenntartására törekednek a foglalkoztatások folyamán.
\end{abstract}

Kulcsszavak: demencia szindróma; demenciabarát környezet; szocioterápiás intervenciók; gondozás

Improving the quality of life of people living with dementia through dementia-friendly conservator exercises

ABSTRACT The study aims to introduce the most important aspect the planned and structured conservator exercises for people living with dementia. Dementia syndroma with ever-growing incidency represents an increasing burden on the shoulders of the society. Institutional background, respite care services and caring family members are under overwhelming pressure day by day to care for people with dementia. Conservator exercises helps to maintain cognitive functioning in the gradually impairing conditions of the clients suffering from such a serious neurodegenerative disorder, like Alzheimer disease (AD). This disease is incurable, but modifiable and in the framework of socio-therapy different forms of conservator exercises may contribute to maintain a relative level of cognitive functioning, communication and interactivity of patients with AD. Very important to maintain the dignity and selfesteem of the patients with $A D$ during these practices.

Keywords: dementia syndrome; dementia friendly environment; socio-therapeutic interventions; nurture 


\section{BEVEZETÉS}

Az OECD a 21. század egyik legnagyobb kihívásaként emlegeti a demográfiai viszonyok megváltozását. A születéskor várható átlagos élettartam az elmúlt 50 évben a fejlett országokban fokozatosan meghosszabbodott (Józan 2011). Az EU egyes régióiban a születéskor várható élettartamok között akár 11 év különbség is lehet. Az Eurostat felméréséből kiderül, hogy a társadalmi, gazdasági és környezeti tényezők hatására 2003 és 2014 között az átlagosan várható élettartam például 3,2 évvel emelkedett. A legnagyobb, nemek közti különbség a születéskor várható élettartam tekintetében Litvániában volt megfigyelhető. Itt a nők átlagosan 10,5 évvel élnek tovább a férfiaknál. Általánosságban az Eurostat (2019) adatai alapján azonban elmondható, hogy ez a nemek közötti különbség folyamatosan csökken. 2015-ben például a nők várható átlagos élettartama 83,3 év, míg a férfiak születéskor várható átlagos élettartama 77,9 év volt. Spanyolországban, Madridban a születéskor várható élettartam 84,5 év, míg Bulgária Severozapaden régiójában ez a szám mindössze 73,5 év.

A demográfiai trendek alapján Magyarországon a demencia további térhódításával számolhatunk. A közismert „idősödő társadalom” kifejezés átfogó folyamatot jelöl. A társadalom elöregedése szinte világszerte új típusú problémákat generál. A szociális és egészségügyi rendszerek működtetése, a jóléti ellátórendszerek fenntarthatósága veszélybe került a kedvezőtlen kormegoszlás miatt. Tanulmányunkban bemutatjuk, hogy a demenciával élők szakellátása során milyen tartalommal és megközelítéssel lehet átgondolt, strukturált formában foglalkoztatási protokollt összeállítani és alkalmazni. A szakellátási formák jelen esetben a tartós intézményi elhelyezést, a napközi otthonos vagy szanatórium jellegű ellátást, illetve az alkalmanként megvalósítható, idős klubokban és a kliensek otthonában történő foglalkoztatásokat jelentik.

\section{A DEMENCIA SZINDRÓMA STÁDIUMAI}

A demencia szindróma 65 évesnél fiatalabb személyeket is érinthet, de általában idős korban jelentkezik és egyre gyakoribbá válik. Az Alzheimer Diseases International (ADI) szerint a demencia szindróma az agyat érintő rendellenességek, valamint a memóriára, a gondolkodásra, a viselkedésre és az érzelmekre gyakorolt hatás által okozott tünetek gyüjtőfogalma (ADI 2020).

A demenciához kapcsolódó jelek és tünetek három szakaszát azonosíthatjuk.

\section{Korai stádium:}

- feledékenység,

- idő dezorientáció,

- ismerős helyek felismerési zavara.

\section{Középső szakasz:}

- homályos emlékezet a közelmúlt eseményeiről és az emberek nevéről,

- saját otthonban való tájékozatlanság,

- egyre rosszabb kommunikáció,

- az öngondoskodás nehézségei,

- viselkedésbeli változások, beleértve a vándorlást, az ismételt kérdezgetést, szóismétlést. 
Késői stádium: a teljes függőség és inaktivitás megjelenése. A memóriazavarok súlyosak és a fizikai jelek és tünetek nyilvánvalóvá válnak.

- térben és időben való tájékozatlanság,

- rokonok és a barátok felismerésének nehézségei,

- a mindennapokban egyre nagyobb szükség van a segítségre,

- járási nehézségek,

- komoly viselkedésváltozások, beleértve az agresszív viselkedést ( WHO 2020).

\section{A DEMENCIA SZINDRÓMA MEGJELENÉSÉNEK DEMOGRÁFIAI SZEMPONTJAI, A PANDÉMIA HATÁSA}

A WHO adatai szerint világszerte mintegy 50 millió ember szenved demenciában. Évente közel 10 millió új esetet regisztrálnak. A 60 éves és idősebb populációban a demencia becsült előfordulási aránya 5-8\% között van. Földünkön a demenciában szenvedők száma az előrejelzések szerint 2030-ban eléri a 82 milliót, 2050-ben pedig a 152 milliót (WHO 2020). Az esetek többségében Alzheimer-kórról van szó. Az Alzheimer Charta (ADI 2008) szerint évente 4,6 millió demencia szindrómában szenvedő beteget regisztrálnak, ez azt jelenti, hogy 7 percenként 1 ember kap ilyen diagnózist. Magyarországon 250-300 ezerre tehető a demenciával élők száma, ebből 160 ezer Alzheimer-kórral él (MNT 2020). Pontos felmérések nem állnak rendelkezésre. Amennyiben a hazai otthoni ellátási helyzetre koncentrálunk, feltételezhetjük, hogy a beteg környezetében élőket, családtagokat is jelentősen befolyásoló, fokozatosan súlyosbodó neurodegeneratív betegség legalább egy családtagot jelentősen érint. Amennyiben ezt a számot növeljük, azt feltételezve, hogy az érintett családtagok, hozzátartozók ennél lényegesen többen vannak, akkor akár egymillió meglehetősen bevonódott, a beteg környezetében lévő emberről beszélhetünk.

A demográfiai változásokat a jelenleg is zajló pandémia szignifikánsan befolyásolja, föként az idősebb populációban. Az új vírust SARS-CoV-2-ként igazolták, a koronavírusjárvány 2019-es (COVID-19) világjárványa 2020. október 15-én világszerte 38752924 beteget jelentett és 1100823 halálesetet okozott. Az országok hasonlóan reagáltak a globális koronavírus járványra a gazdasági tevékenységek és a társadalmi kapcsolatok korlátozásával (Ryoo et al. 2020).

A COVID-19 világjárvány hatására hazánkban az elhunytak száma 2021 tavaszán (március, április eleje) kiugróan magas, több mint napi 200 volt. A jó oltási arány ellenére Magyarország a lakossági létszámra kivetített halálozások terén az élen járó országok kategóriájába került (WHO 2021).

\section{KEZELÉS ÉS GONDOZÁS}

Intézményekben élőknél a szociológiai értelemben totális intézményrendszer szabályozza a kapcsolattartást, környezetet, időrendet, kapcsolati hálót, házirendet, napirendet, a napi programokat. Mindez nagy felelősséget ró az intézmények menedzsmentjére, a dolgozó, foglalkoztató, ellátó munkaközösségre. A demenciával élők, gondozásuk kihívásai intenzíven formálják a körülöttük élők, őket ellátók, gondozók életét, erőfeszítéseit, attitűdjeit. 
Jelenleg nem áll rendelkezésre olyan oki terápia, amely a demenciát gyógyítaná, de kezelése, a tünetek csökkentése, a betegek gondozása és ápolása jelenti a beavatkozási lehetőségeket. Sokat lehet tenni a demenciában szenvedők, gondozóik és családtagjaik támogatása, életminőségük javítása érdekében. A nappali ellátórendszer bővítése, a demenciával élőket gondozók edukációja, a hozzátartozók tehermentesítése, lelki egészségük védelme alapvető, és társadalmi, gazdasági előnyöket is jelent (Kovács 2019).

\section{KOCKÁZATI TÉNYEZÖK ÉS MEGELÖZÉS}

Bár az életkor a demencia legerősebb ismert kockázati tényezője, a demencia szindróma nem elkerülhetetlen következménye az öregedésnek. A demencia nem kizárólag az idősebb embereket érinti - a fiatalkori demencia (amelyet a tünetek 65 éves kor előtti megjelenéseként határoznak meg) az esetek legfeljebb 9\%-át teszi ki.

A kutatási tapasztalatok azt mutatják, hogy az emberek csökkenthetik a demencia kockázatát azáltal, hogy a rendszeres fizikai aktivitást, mozgást beiktatják az életükbe, mellőzik a dohányzást, kerülik a túlzott alkoholfogyasztást, elhízást. Egészségesen táplálkoznak, ebben föként a mediterrán étrend ajánlható. A vérnyomás-, koleszterin- és vércukorszint egészséges értékek között tartása, monitorozása elengedhetetlen. Kockázati tényezők közé tartozik a depresszió, az alacsony iskolai végzettség, a társadalmi elszigeteltség és a kognitív inaktivitás (WHO 2020).

\section{A JÓL MÜKÖDÖ FUNKCIÓK MEGERÖSÍTÉSE, A FOGLALKOZTATÁS PERSPEKTIIVÁI}

A mentális hanyatlásban szenvedő ember egészséges tulajdonságaira, megtartott funkcióira sikeresen lehet építeni. A megmaradt képességeket, ép funkciókat erősíthetjük. Önellátó képességüket, életminőségüket hosszabb ideig fenntarthatjuk, ha megfelelő ismeretek birtokában szakszerü segítséget nyújtunk számukra, úgy, hogy közben önérzetük, önbizalmuk a lehető legkevésbé sérüljön. A további állapotromlás késleltetéséhez különböző terápiákat, foglalkozásokat, játékos gyakorlatokat alkalmazhatunk. A feladatok és a játékok jelentős része szórakoztatja őket és leköti a figyelmüket. Hozzájárulhat a meglévő képességek és készségek megőrzéséhez, szinten tartásához. Erősítheti az öregedéssel kapcsolatos pozitív attitüdök kialakulását. Új perspektívákat kínálhat, új készségek felfedezését segítheti elő. Oldódik a feszültség, csökken a fáradtságérzés, csökkenthetők a depresszív tünetek, megújul a testi-lelki teljesítőképesség. Élménydúsabbá és tartalmasabbá válnak a mindennapok számukra. A napi rendszerességgel végzett tevékenységek biztonságot eredményeznek, csökkentik a zürzavart, a bizonytalanság elhatalmasodását. A szervezett, eseményteli életmód strukturálttá teszi mindennapjaikat (Kosztáné - Somorjai - Török 2020). 


\section{DEMENCIABARÁT MEGKÖZELÍTÉS}

Ebben a témakörben kiemelhető Virginia Bell „legjobb barát” modellje. Az USA-ban élő lexingtoni orvos több mint 20 éve foglalkozik demenciával élőkkel. Nevéhez füződik az első demenciaspecifikus napközi program, valamint az Alzheimer-betegek jogainak kidolgozása. A legjobb barát modell a demenciában szenvedő betegek mentális gondozásának a színvonalát kívánja emelni és a legáltalánosabb értelemben ajánlható a professzionális és laikus gondozók számára. A megközelítés szerint a betegnek leginkább egy jóbarátra van szüksége, aki ismeri az egész életútját és ennek figyelembevételével bánik vele (Bell - Troxel 2007).

Minden idős személy egyik legnagyobb félelme a haszontalanság és a feleslegesség érzése. A gondozónak meg kell találnia azokat a tevékenységeket, amitől az idős ember azt érzi, hogy a megmaradt képességei birtokában értéket képviselő foglalatosságokat képes elvégezni. A vezetés módszertanában, a versenyszférában is alkalmazott módszer és elv az „empowerment”, képessé tétel, hatalommal való felruházás. A demenciában szenvedőket is fel kell hatalmazni azzal a képességgel, hogy hanyatlásuk közepette is át tudnak adni valamit másoknak, betegtársaiknak. A procedurális - cselekvésekben megnyilvánuló - tudás náluk is sokáig megmarad. Ennek igen jelentős terápiás szerepe van a foglalkoztatásuk folyamán.

A fent bemutatott szemléletből adódik a személyre szabott bánásmód gyakorlata, ami alkalmazkodik az egyén megtartott kognitiv teljesítőképességéhez, fizikai állapotához.

A kisebb közösségek életébe való bekapcsolódásuk kiemelt jelentőségü. Biztosítani kell számukra, hogy képesek legyenek másokkal interakcióba lépni, társas kapcsolatokat kialakítani. Természetesen mindebben állapotuknak megfelelő segítségre szorulnak. A szellemi és kognitív képességek szinten tartására használatos játékos feladatokat be kell iktatni a betegek mindennapjaiba, mint ahogyan a szórakoztató és szabadidős tevékenységeknek is helyet és alkalmat kell találni. A családi és társadalmi kapcsolatok fenntartása az érzelmi, hangulati állapot egyensúlyban tartásához nagy segítség lehet.

\section{A SZÉLESEBB ÉRTELEMBEN VETT FOGLALKOZTATÁS ALKALMAZHATÓSÁGÁNAK SZAKIRODALMI EVIDENCIÁI}

A szociális támogatás pozitív jelentősége az öregedés folyamatában számos metaanalízisben megerősítést nyert. Holt-Lunstad munkatársaival (2010) összesen 148 kutatás - 300000 résztvevőt érintő - tanulmányozásának eredményeképpen kimutatta, hogy a szociális támogatás 48\%-kal növeli a túlélés valószínűségét. Az elemzett kutatások az Egyesült Államokra, Európára, Ázsiára és Ausztráliára terjedtek ki. Fontos kiemelni, hogy a szociális támogatás és a kedvezőbb túlélés kapcsolata kiegyensúlyozottnak bizonyult a kor, nem, geográfiai övezet, kezdeti egészségi státusz és a halálok figyelembe vétele mellett is. Shor, Roelfs és Yogev (2013) kimutatta, hogy a családi erőforrásokból táplálkozó szociális támogatás különösen erős bejóslója az alacsonyabb mortalitásnak.

A gerontológiában fontos longitudinális vizsgálatsorozatként ismert „nővér kutatás” („nun study") számos érvet sorakoztatott fel amellett, hogy a napi rendszerességű imádkozás és kontempláció preventív hatással bír az Alzheimer-betegség kialakulására. Egyben ezek a tevékenységek javítják azoknak a nővéreknek az állapotát is, akiknél már jelentkeztek a betegség tünetei (Snowdon 2008). A meditáció, akár vallásos vagy spirituális tartalommal vagy szekulá- 
ris formában jó hatással lehet az időskori kognitív működésre (Gard et al. 2014 ). Newberg és munkatársai (2014) a neurodegeneratív betegségekben szenvedő betegeknél alkalmazott meditációnak elsősorban a figyelmi és memóriamüködésre való pozitív hatásáról számolnak be összefoglaló elemzésünkben. Peter G. Coleman és munkatársai (2016), összefoglalva számos kapcsolódó kutatás és tanulmány eredményeit, rámutatnak, hogy a vallásos aktivitások különböző módon stimulálhatják a kognitív aktivitást. A vallásos tevékenységekben megjelenő elemek közül a koncentráció, az introspekció, meditáció, perspektívaépítés, absztrakt gondolkodás és kontempláció vonható ebbe a körbe. Az előbbi aktivitások olyan különböző kognitív modalitásokat befolyásolhatnak pozitív módon, mint az észlelés, megértés, rendezés, és befolyásolják az érzelmi folyamatokat is. A különböző memóriarendszerek müködésének stimulálásával befolyásolják a frontalis lebeny aktivitását. A figyelmi folyamatok és a rövid idejü memória aktiválása a prefrontális kéregállomány fokozott működésével jár.

Robert S. Wilson és munkatársai 2007-ben publikált tanulmányukban 700 idős ember 5 éves utánkövetéses vizsgálata során azt találták, hogy közülük 90 egyénnél alakult ki Alzheimer-betegség. Azoknál, akik rendszeresebben vettek részt kognitív aktívitásban, alacsonyabb volt a betegség előfordulása. A kognitív szempontból inaktív időseknél 2,6-szoros valószínüséggel alakult ki a betegség aktív társaikhoz képest. A kognitív aktívitás az enyhe mentális hanyatlással való összefüggésben $(\mathrm{MCl})$ is csökkent előfordulási gyakorisággal járt együtt. Ugyancsak Robert R. Wilson vezette azt a kutatócsoportot, amely 808 katolikus egyházi szolgálatot teljesítő idős személyt vont be átlagosan négy és fél éves utánkövetéses vizsgálatba és az előző vizsgálat eredményeit megerősítő konklúzióhoz jutott, miszerint a rendszeres kognitív aktivitás csökkenti az Alzheimer-betegség előfordulásának kockázatát ( Wilson et al. 2002). A „hibamentes tanulás” bevált módszer a memóriakárosodásban szenvedők új információkra való befogadásának fejlesztésében, amely figyelembe veszi az alany aktuális teljesítményszintjét. Hong Kong-i kutatók által vezetett komputerizált, az 1999-2011 közötti nemzetközi szakirodalom áttekintésével megvalósuló elemzés arra az eredményre vezetett, hogy a hibamentes tanulás speciális módszerével kivitelezett tréningek hatékonyak felnőtt, Alzheimer-betegségben szenvedő egyének memóriájának rehabilitációjában. Ezek a speciális tréningek az információknak a memóriában való megtartását segítették elő a vizsgálatokban részt vett egyéneknél (Li - Liu 2012).

Szólista tanulás és felismerés speciális feladataiból álló, rövid memóriatréninggel történt beavatkozás mérsékelt tanulási és memória nyereségekkel járt 34 Alzheimer-kórral diagnosztizált beteg vizsgálatánál. Az előnyt nem lehetett általánosítani más neuropszichológiai mérőeszközökkel vizsgálható kognitív funkcióknál (Cahn-Weiner 2003).

Az Alzheimer-betegség fokozott kockázati tényezőit mutató, de még a kórral nem diagnosztizált kognitív müködést stimuláló videojátékokat gyakran használó felnőtteknél a játék nem csupán magasabb mérhető kognitív funkcionálással járt, hanem kimutatható volt a nagyobb szürkeállomány is (Schultz et al. 2015).

Ehhez kapcsolható annak az epidemiológiai kutatásnak az eredménye, ami élethossziglani kognitív aktivitást vizsgálva egészséges időseknél a magasabb fokú kognitív aktivitás és az alacsonyabb fokú hipokampális atrófia közötti kapcsolatra utalt (Valenzuela et al. 2008).

Landau és munkatársai (2012) vizsgálatukban azt találták, hogy azok az idősek, akik gyakrabban merülnek bele különböző kognitív aktivitásokba, hasonló amylod szintet mutatnak, mint a fiatalabb kontrollcsoport tagjai. Ellenben azok az idősek, akik a legkevesebb kognitív 
aktivitással jellemezhetők, az amyloid szinjüket illetően az Alzheimer-betegekre jellemző övezetbe tartoznak. Mind az amyloid szint paramétere mint a hippocampus neuroanatómia struktúrája olyan tényezők, amelyeknek a betegségben való érintettsége egyértelműen kimutatható az Alzheimer-kórban szenvedőknél.

Az Alzheimer-betegség később jelenik meg az iskolázottabb egyéneknél, de a diagnózis után gyorsabb hanyatlás jelentkezik náluk (Stern et al. 1999).

Ugyanakkor a kognitív funkciók fejlesztésének neuropszichológia mérőeszközökkel történő regisztrálása, ezek pozitív változásai számos célzott kutatásban nem jártak együtt mérhető változásokkal az Alzheimer-betegségben elsődleges érintett neuroanatómia struktúrák vonatkozásában.

\section{A FOGLALKOZTATÁS SZEREPE ÉS TARTALMA}

A foglalkoztatás maga az aktivitás, széles értelemben véve számtalan tervezett, rendszeres tevékenység foglalkoztatásnak minősül. Melyek azok a tevékenységek, amelyek jól illeszthetők a demenciabarát szemlélethez? Ide sorolhatók a memóriatréningek és számos rekreációs tevékenység. Fontos hangsúlyozni, hogy a foglalkoztatás tartalmi része hozzáférhetővé kell, hogy váljon a szakmai közösség professzionális segítőin túl a legszélesebb értelemben vett nagyközönség számára is. Ezt a demencia szindrómával élő betegek nagy és egyre emelkedő száma is indokolttá teszi, akiknek a gondozása nagymértékben a családi gondozókra nehezedik. A foglalkoztató anyagok, módszerek hozzáférhetősége, a gyakorlatok kivitelezhetősége, megosztásának lehetőségei motiváló lehet azon családtagok, hozzátartozók számára is, akik túl akarnak lépni a demencia szindróma diagnosztizálása utáni sokkon, vagy a betegség súlyosbodásával gyakran a családtagoknál is jelentkező kétségbeesés és nihilizmus fázisain. A demenciával élő életéből nem hiányozhatnak a fizikai és szellemi aktivitások, a mindennapi rekreációs tevékenységek. A még egészséges agysejtek kondíciójának megőrzéséhez nélkülözhetetlenek a memóriajátékok és egyéb agytréningek, különben az állapotromlás és annak egyre gyorsuló üteme válik detektálhatóvá. Foglalkoztatások és a tevékeny hétköznapok hiányában garantált az érzelmi és hangulati zavarok gyakori megjelenése vagy állandóvá válása. A képességvesztésük tudatosulása önérzetüket, önbizalmukat is mélypontra viszi.

A memóriabetegek számára a legfontosabb a szeretet és a figyelem. Az, hogy minden körülmények között emberségesen bánjunk velük, függetlenül attól, hogy értelmi képességeik hanyatlása milyen szinten tart. Közérzetüket, komfortérzetüket nagyban befolyásolja az, hogy hogyan bánik velük a környezete. Fontos elv, hogy a dolgok nem rajta kívül, hanem vele együtt változzanak. A tanult tehetetlenségre való szocializáció helyett aktív, környezetet alakító helyzet kialakítására törekedjünk. A cél az egyéni tudatos cselekvő ember és a közösségben másokkal együttműködő partnerségre és elismert méltóságra épülő közös cselekvésben részt vevő emberi magatartás elérése. Amikor már a szavakkal nem tudjuk megértetni magunkat, a testbeszéd, a metakommunikáció minden eszközrendszere az, ami kifejezi érzésünket, hajlandóságunkat a beteg felé. Mivel az érzelmek iránti fogékonyságuk sokáig megmarad, egy „negatív" taglejtés egy rossz arcfintor is elég ahhoz, hogy bizalmatlanok legyenek és eluralkodjon rajtuk a feleslegesség érzése. 


\section{DEMENCIABARÁT GONDOZÓI LÉGKÖR KIALAKÍTÁSÁT SEGÍTŐ SZEMPONTOK}

Minden demenciával élő személy egyedi. Képességeik különbözőek. Ezt feltétlen tartsuk szem előtt, amikor feladatot, játékot választunk a számukra. Képességeikhez, meglévő tudásukhoz mért legyen a kiszemelt játékos feladat. A lehetőségeknek megfelelően tudassuk demenciával élő gondozottunkkal vagy ebben szenvedő családtagunkkal, hogy minden a képességei erősítése, megőrzése érdekében történik, és ne szégyenkezzen, ha valami nem jut az eszébe. Így elkerülhetjük a kudarcélményt, a megszégyenülést, emelhetjük a részvételi hajlandóságot. A foglalkozások tartásánál a legfontosabb a megfelelö, tapintatos bánásmód, a hangnem megtalálása, a támogató légkör kialakítása. Kerülendők az oktató, számonkérő, iskola jellegü foglalkozások. Mindig hagyjunk kellő időt a válasz megszületésére, a véleménynyilvánításra. Ne sürgessük őket, hanem türelemmel és megértéssel forduljunk feléjük. Ha nem sikerül a megoldás, finoman próbáljuk rávezetni őket, de vigyázzunk, hogy ne legyünk túl erőszakosak. A szeretet, a biztonság éreztetése az igazi kulcs az aktivitásuk eléréséhez, motiválásukhoz. Kedvező, ha van sikerélményük, így a motiváltsági szint továbbra is fenntartható. Legyünk partnerek a játékokban, próbáljuk együtt megoldani velük a feladatokat, akkor ők is szívesebben fognak csatlakozni a közös aktivitásokhoz.

A foglalkoztatások széles köréből merítve helyenként részletes leírásokkal és ábrákkal demonstrálva mutatunk be számos gyakorlatot, remélve, hogy ezzel tanulmányunk plasztikusabb, érthetőbb és adott esetben alkalmazhatóbb lesz.
A foglalkoztatás formai keretei:
- Egyéni foglalkoztatás,
- kiscsoportos foglalkozás,
- nagycsoportos (közösségi foglalkoztatás).

\section{A foglalkoztatások területei:}

I. Érzékelés, észlelés, (percepció) erősítése tapintás, vizuális érzékelés, hallás, szaglás, ízérzékelés, mozgás;

II. Realitásorientáció;

III. Memória- és beszédmegtartást segítő interakciós játékok;

IV. Magatartásorientáció, interaktív gyakorlatok;

V. Egyéb rekreációs gondolatébresztő játékok.

\section{JÁTÉKOS MEMÓRIATRÉNINGEK KÍNÁLATA}

Az alábbiakban válogatást mutatunk be - a teljesség igénye nélkül - a különféle memóriatréningekből és a közösségi aktivitások különféle területeit is érintjük.

\section{I. Érzékelés, észlelés (percepció) erősítése}

A kor előrehaladtával az érzékszervek müködései is fogyatkoznak. A látás-, hallásveszteség, ízérzékelés, szagláscsökkenés csak fokozza a demenciával élő bizonytalanságát. Kevesebbet érzékel a világból, mint azelőtt, amely erősíti a kirekesztettség érzését. A gyakorlatok során felidézés, ismétlés által erősíthetjük az érzékelést. Ebben a kategóriában végezhetünk tapintás- 
ra, vizuális érzékelésre (látás), hallásra, mozgásra, szaglószervre, ízérzékelésre kiterjedő játékos feladatokat.

1. Tapintás (ezt a területet dolgozatunkban nem mutatjuk be részletesen)

2. Vizuális érzékelés

2.1. Formák felismerése zsúfolt ábrában

Készíthetünk különböző ábrákat, rajzokat, ahol a formák átfedik egymást, csak színben különböznek. A játék lényege, hogy a kusza ábrákon látható dolgokat megnevezze.
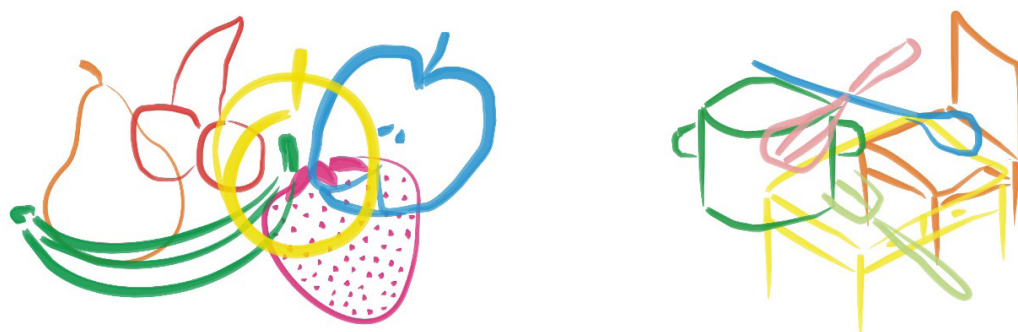

1. ábra Formák felismerése zsúfolt ábrában

Forrás: Kosztáné 2010

\subsection{Különbségek felismerése képeken, rajzokon}

Készíthetünk olyan ábrákat (akár kézzel is) amelyek látszólag hasonlóak, de apró részleteiben eltérnek egymástól, mint például a következők:
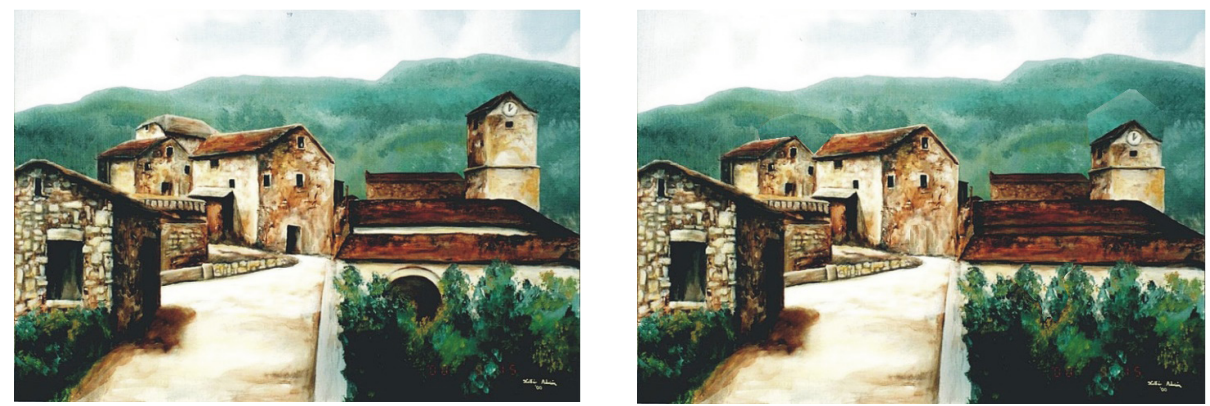

2. ábra Különbségek felismerése

Forrás: Kosztáné 2010

Ehhez hasonló ábrákat, képeket különböző nehézségi fokon készíthetünk és ha csoportban játszunk, minden egyes játékosnak adhatunk egy ábrát, majd a feladat megoldását követően cserélgetjük őket, így mindenkihez kerül majd könnyebb és nehezebb feladvány. 


\subsection{Vizuális neglekt (kiesés vagy figyelemhiány)}

Vonalak áthúzása: Egy papírlapra elszórtan felrajzolt vonalakat kell a vizsgált személynek egyesével áthúznia egy színes ceruzával

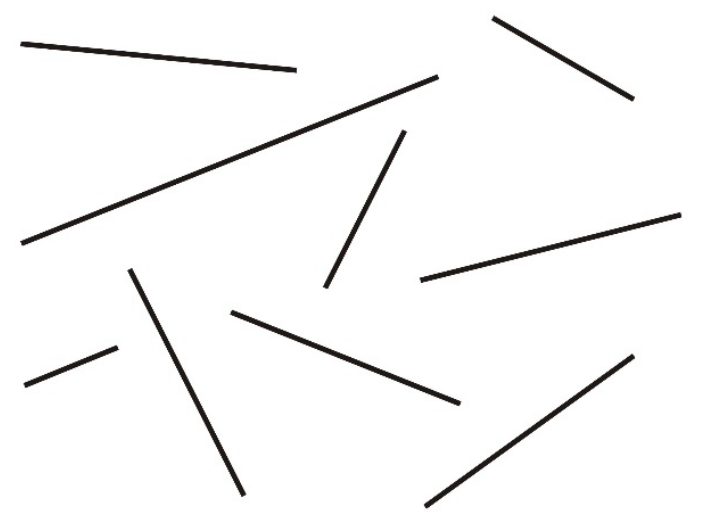

3. ábra Vonalak áthúzása

Forrás: Test of Visual, Neglect Albert 1973

Vonalfelezési feladat: Egy lapra rajzolt különböző elhelyezkedésű vízszintes vonalak felezőpontját kell a vizsgált személynek megjelölnie.

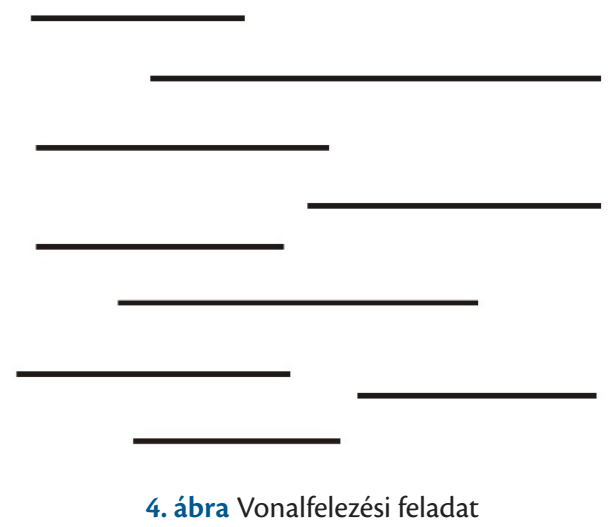

Forrás: Line Bisection Test, Rajna, P. - Tariska, P. (2000) 
Vizuális keresési teszt: Az $5 \times 5$-ös rácsozatban különböző mezők közül két azonos ábrát kell keresnie a vizsgált személynek.
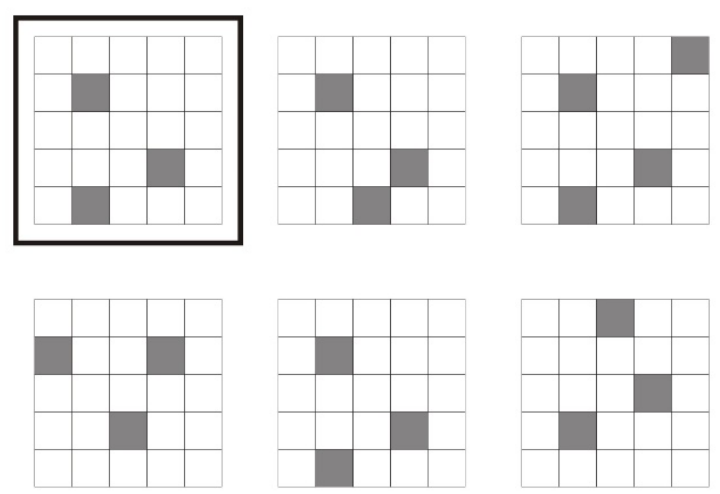

5. ábra Vizuális keresési teszt

Forrás: Visual Searc Goldstein, Rajna és Tariska, 2000

Szavak megfejtése: A vizsgált személynek a hiányzó betűkkel bemutatott szavakat kell megneveznie.

\section{Mintaszavak}

CIPŐFÚZŐ

CSIZMA

CERUZA

\section{BALATON}

KESZTYÜ

\section{$\mathrm{DOBOZ}$}

\section{PAPUCS}

CSAVAR

6. ábra Szavak megfejtése

Forrás: Tariska, P. 2002 


\section{Hallás (akusztikus képességek)}

Hallással sok információt nyerünk a környezetünkről, ha valakinek romlik a hallása, akkor nem képes jól kommunikálni és kevesebb információt kap a külvilágról, az őt körülvevő eseményekről. Ha érzékszerveink hiányosan működnek, az bizonytalanságot, szorongást eredményez. Nagyobb esélye van depresszió kialakulására, elszigetelődésre, erősödik a félelem, kialakulhat paranoia. Így erősíthetjük a hallás által nyert információk tudatosítását az agyban különféle gyakorlatokkal (egyes gyakorlatokra csak röviden utalunk).

3.1. Környezeti zajok, hangok felismerése

3.2. Hallás utáni szóismétlés

3.3. Mondatismétlés hallás után

3.4. Hallás utáni történetfelidézés

\section{Realitás (orientációs) tréning}

A realitásorientáció a valósággal való folyamatos kapcsolattartás, más néven 24 órás ROTtréning lényege, hogy a beteggel való kommunikáció során aktuális és valós adatokat közlünk számára. A beteget a keresztnevén szólítjuk, és folyamatosan tájékoztatjuk arról, hogy éppen mi történik, hol van, mit fogunk közösen csinálni.

Végezhetjük egyéni beszélgetés keretében vagy csoportosan. Különböző témakörben beszélgetéseket szervezünk, ahol a csoporttagok mesélnek magukról a társaiknak a régi életükről (gyerekkor, iskoláskor felnőttkor, családi események, kirándulás). Azzal, hogy beszélnek magukról társaiknak, folyamatosan tudatosul bennük, hogy kik ők, hány évesek, hol vannak és mi történik velük. A klubtagok, csoporttagok kohézióját, összekovácsolódását is nagymértékben elősegíti.

\section{Strukturált realitás orientációs tréning}

Ezen típusú foglalkozásban az újratanulás és a reszocializácó, az önellátó képesség megtartására koncentrálunk. Lényege, hogy gyakran ismételjük a jelen eseményeit, milyen évszakban, hónapban, hét napjában vagyunk, hány óra van, beszélhetünk az időjárásról, melyek a hét legfontosabb hírei a szűk családban, környezetünkben, a nagyvilágban. Minden olyan információt hasznos lehet, amely a valóság felé orientálja a klienseket.

\section{Standard realitás orientációs tréning}

A szociális interakciók, a társas kapcsolatok kialakulását, támogatását segíti elő. Egyéni beszélgetés vagy csoportos foglalkozás keretében zajlik, különböző témakörökben, a csoport érdeklődésének megfelelően.

Memória- és beszédmegtartást segítő interakciós játékos feladatok

A szójátékokkal elősegítjük a mindennapi kommunikációt, segítünk abban, hogy az általunk ritkán vagy egyáltalán nem használt szavak minél tovább az emlékezetünkben maradjanak, nélkülözhetetlen a szókincs, a mindennapi kommunikáció megtartásához, erősítéséhez. A régi és az új szavak használatával a kifejezőkészségüket, megértésüket egyaránt segítjük. $\mathrm{Az}$ idetartozó konkrét gyakorlatokat csak címszavakban említjük: asszociációs játékok, szólánc játék, közmondások és szólások befejezése, szinonimák keresése. 


\section{Magatartásorientációs, intervenciós gyakorlatok}

1. A relaxációs módszerek is hatékonyak lehetnek, de itt figyelembe kell venni azt, hogy a demencia szindróma mely stádiumában van a kliens. Az enyhe fokú demenciában szenvedőknél lehet jó hatása a progresszív (Jacobson-féle) relaxációnak, illetve az autogén tréning egyes elemeinek.

\section{Zeneterápia}

„A zeneterápia célja, hogy az egyén lehetőségeit feltérképezze, és/vagy sérült funkcióit helyreállítsa, így jobb intrapszichés és/vagy interperszonális integrációt tegyen lehetővé, s a prevenció vagy a rehabilitáció vagy a kezelés következtében a személy minőségileg jobb életet élhessen." (Urbánné 2005: 99-116). A zene érzelmeket fejez ki és érzelmeket ébreszt s ez a hívó erő „kommunikációs hidat épít, amely elősegíti a korábbi élmények reaktiválását, újra élését.” Mérések igazolják, hogy az aktív bevonódás és az érzelmek ereje a szívverésre és a légzésszámra is hat, elősegíti a kapcsolatépítést, és csökkenti a nyugtalanságot. A zene önmagában is hat fizikai, érzelmi, szociális és kognitív állapotunkra, minőségi változást okoz ezeken a területeken (Csere - Stánicz 2019).

3. Kellemes emlékek módszeres felelevenitése (reminiszcencia tréning)

Egyénileg és csoportban is elvégezhető emlékelőhívó foglalkozás, kellemes emlékeket felidéző fényképek bemutatásával. Ez a módszer közösségépítő, csoportkohéziót erősítő jelenséggel is bír, egymást kölcsönösen megismerik, illetve könnyebben találnak így beszélgetésre alkalmas témát. Ezzel is elősegíthető a csoporttagok egymás közötti kommunikációja, beszédmegtartás, kapcsolatépítés, szocializáció.

Fontos hangsúlyozni, hogy ezek a tevékenységek nem a demenciával élő ember képességeinek fejlesztését célozzák. A cél az állapotromlás mérséklése. A jól megválasztott tevékenységek, a pozitív én-élmények erősítik az identitástudatot, a sikerélmény a „még tudok valamit”, „vagyok valaki” érzését nyújtja a demenciában szenvedő betegnek (Kosztáné - Somorjai - Török 2020: 10-12).

\section{Szocioterápiás keret a demenciával élők foglalkoztatásában}

A szocioterápia az egyén társas kapcsolatainak, társadalmi környezetének pozitív hatásaira épülő terápiás beavatkozás, mely a szociális tanulást és a kreatív önmegvalósulást segíti. Célja a beteg tevékenységének helyreálítása, az elveszett képességek visszaadása, a társadalomba való visszahelyezés, a mindennapi életre való felkészítés, az önellátásra való képesség kialakítása, a harmonikus visszailleszkedés elősegítése (Horváth 2004).

A szocioterápia célja, hogy más megközelítésben teret adjon újfajta tevékenységeknek, amely által a személyiségben rejlő lehetőségek kerülnek a felszínre, így ez egy kiegészítő jellegű terápiás tevékenység.

A kreatív és müvészetterápiák is fontosak a demenciával élők foglalkoztatási repertoárjában, azonban bemutatásukkal már túllépnénk jelen tanulmány kereteit. Ezekről a formákról hozzáférhető és a témákat széleskörűen tárgyaló publikációk állnak rendelkezésre. A mozgásterápiáról, művészet- és kreativitás-terápiáról, valamint bővebben a zene- és táncterápiáról a 2020-ban megjelent, Somorjai Ildikó által szerkesztett „Együtt töltött Idő, közösségi játékok és aktivitások demenciával élőknek" című müben található bővebb információ. 


\section{Összegzés}

A demencia szindróma nagy megterhelést jelent a demenciával élők és gondozóik, hozzátartozóik számára. Kihívás elé állítja a szűkebb és tágabb szociális környezetet, az ellátó rendszert, az érintett szociális intézményeket, a szakemberek széles körét. Tanulmányunkban többek között áttekintettük a demencia epidemiológiájának, megelőzésének, kezelésének szempontjait, kitérve a COVID-19 pandémia hatásaira is. Bemutattuk a demenciával élők foglalkoztatásának perspektíváit, taglaltuk a foglalkoztatások széleskörü alkalmazhatóságának szakirodalmi evidenciáit, mindezt demenciabarát megközelítéssel. A gondozói légkör kialakítását segítő szempontok, modellek, a beavatkozások és a különböző tréningek bemutatása szándékunk szerint a szociológia tudományában jártas olvasó számára is plasztikus képet rajzol a terápiás nihilizmuson túllépő módszertani lehetőségekről. Egyben a szocioterápia keretében gyarapodó, foglalkoztatásokkal kapcsolatos tudás számos érdeklődőt, vagy éppen valamilyen szempontból a demencia szindróma megjelenésében érintettet is bevonhat jelen dolgozat bizonyos témaköreibe. Természetesen a foglalkoztatások bemutatása nem lehet teljes, a szerzők célja az volt, hogy praktikus ízelítőt adjanak a széles repertoárból, elsősorban a vizuális modalitásból kínálva több példát. A dolgozat ráirányítja a figyelmet arra, hogy a demenciával élők életéből nem hiányozhatnak a fizikai és szellemi aktivitások, a mindennapi rekreációs tevékenységek. Foglalkoztatások és a tevékeny hétköznapok hiányában garantált az érzelmi és hangulati zavarok gyakoribb megjelenése vagy állandóvá válása. Önellátó képességüket, életminőségüket hosszabb ideig fenntarthatjuk, ha megfelelő ismeretek birtokában, demenciabarát hozzáállással szakszerű segítséget nyújtunk számukra úgy, hogy közben önérzetük, önbizalmuk a lehető legkevésbé sérüljön. Hangsúlyozandó, hogy a foglalkozások szervezői, kivitelezői, legyenek akár professzionális gondozók, segítő szakemberek, gondozó családtagok, hozzátartozók, vagy „laikus” segítők, saját maguk is gyarapodnak tapasztalatokkal, tudással, hozzáértéssel és nem utolsósorban meg-megújítható reménnyel, hogy ezen a nehéz területen is érdemes jobbítani, tenni, változtatni. Ezzel nemcsak a gondozottakat, hanem saját magukat is egy élhetőbb, méltóbb emberi viszonyrendszerbe helyezik, még a nagyon nehéz, gyakran drámai helyzetekben is.

\section{IRODALOM}

Albert, M. L. (1973): A simple test of visual neglect. Neurology, (23)6: 658-664. https://doi. org/10.1212/WNL.23.6.658

Alzheimer Diseases International - ADI (2008): Globális Alzheimer Charta. London: ADI. http://www.alzheimerweb1.hu/pdf/globalis-alzheimer-charta.pdf (utolsó letöltés 2021.02. 01.)

Alzheimer Diseases International - ADI (2020) : Symptoms of dementia. Diagnosis. Important of early diagnosis. London: ADI. https://www.alzint.org/about/symptoms-of-dementia/ importance-of-early-diagnosis/ (utolsó letöltés 2021.02.01.)

Bell, V. - Troxell, D. (2016): The Best Friends Approach to Dementia Care, Second Edition. Baltimore: The Health Professions Press, 116. 
Cahn-Weiner - D. A., Molloy - P. F., Rebok - G. W. - Ott, B. R. (2003) : Results of a randomized placebo-controlled study of memory training for mildly impaired Alzheimer's disease patients. Applied Neuropsychology (10)4: 215-223. https://doi.org/10.1207/s15324826 an1004_3

Coleman, G. P. - Schröder-Butterfill, E. - Spreadbury, J. H. (2016): Religion, Spirituality, and Aging. In: Bengtson, L. V. - Settersten, A. Jr. (eds.): Handbook of Theories of Aging. Third Edition. New York: Springer Publishing Company, 656-679.

Csere, M. - Stánicz, M. (2020): Zeneterápia a geriátriában. Oktatási anyag. PTE, Zeneterápiás szakirányú képzés. 2019/2020. II. félév. Pécs: PTE.

Eurostat (2019): Ageing Europe Looking at the lives of older people in the EU - 2019 edition. Luxembourg: Publications Office of the European Union https://ec.europa.eu/eurostat/documents/3217494/10166544/KS-02-19\%E2\%80\%91681EN-N.pdf/c701972f-6b4e-b432-57d2-91898ca94893 (utolsó letöltés 2021.02.01.)

Gard, T. - Hötzel, B. K. - Lazar, S. W. (2014) : The potential effects of meditation on age-related cognitive decline: a systematic review. Ann N Y Acad Sci, 1307: 89-103. https://doi.org/ $10.1111 /$ nyas. 12348

Holt-Lunstad, J. - Uchino, B. N. - Smith, T. W. - Hicks, A. (2007): On the importance of relationship quality: The impact of ambivalence in friendships on cardiovascular functioning. Annals of Behavioral Medicine: A Publication of the Society of Behavioral Medicine, (33)3: 278-290. https://doi.org/10.1007/BF02879910

Horváth, Sz. (2004): A szocioterápia szakmai protokollja. A Pszichiátriai Szakmai Kollégium állásfoglalása a pszichiátriai zavarok gyógykezeléséről. Budapest: Egészségügyi Minisztérium. https://www.scribd.com/document/357326792/Szocioterapias-protokoll (utolsó letöltés 2021.02.01.)

Józan, P. (2011): A népesség néhány öregkori jellemzője. In: Semsei I. (szerk.): Gerontológia, Egészségügyi kari jegyzetek. Nyíregyháza: DE Egyészségügyi Kar.

Kosztáné Hadházi, T. 2010: Játékok a mentális egészségünkért. foglalkoztató munkafüzete. I. Budapest: Creo,

Kosztáné Hadházi, T. (2012): Játékok a mentális egészségünkért. foglalkoztató munkafüzete. II. Budapest: Creo.

Kosztáné Hadházi, T. - Somorjai, I. - Török, E. (2020): Együtt töltött Idő, Közösségi Játékok, aktivitások demenciával élőknek. Budapest: Tégy az Idősekért Alapítvány, 10-12.

Kovács, T. (2019) : Interprofesszionális együttműködési lehetőségek az egészségügyben: A dementia diagnózisa és kezelése. Interprofesszionális Demencia Alapprogram. Budapest: Magyar Katolikus Szeretetszolgálat. https://inda.info.hu/szakember-vagyok/szakertoi-dokumentumok (utolsó letöltés: 2021.02.01.)

Landau, S. M. - Marks, S. M. - Mormino, E. C. - Rabinovici, G. D. - Oh, H. - O’Neil, J. P (2012): Association of lifetime cognitive engagement and low beta-amyloid deposition. Archives of Neurology (69)5: 623-629. https://doi.org/10.1001/archneurol.2011.2748 
Li, R. - K. P. Y. (2012): The use of errorless learning strategies for patients with Alzheimer's disease: a literature review. Int J Rehabil Res, (35)4: 292-298. https://doi.org/10.1097/MRR. ob013e32835a2435

Magyar Neurológiai Társaság - MNT 2020: 2050-re megháromszorozódik az Alzheimer betegek száma. Budapest:MNT.http://www.miet.hu/hir/39605/2050-re-megharomszorozodikaz-alzheimer-betegek-szama (utolsó letöltés: 2021.02.01.)

Newberg, A. B. - Serruya, M. - Wintering, N. - Moss, A. S. - Reibel, D. - Monti, D. A. (2014): Meditation and neurodegenerative diseases. Annals of the New York Academy of Sciences, 1307: 112-123. https://doi.org/10.1111/nyas.12187

Rajna, P. - Tariska, P. (2000): Az idős kor neuropszichiátriája. Budapest: Btv Kiadó.

Schultz, S. - Larson, J. - Oh, J. - Koscik, R. - Dowling, M. N. - Gallagher, C. L. - Cynthia M. Carlsson - C. M. - Rowley, H. A. - Bendlin, B. B. - Asthana, S. - Hermann, B, P. - Johnson, S. C. - Sager, M. - LaRue, A. - Okonkwo, O. C. (2015): Participation in cognitivelystimulating activities is associated with brain structure and cognitive function in preclinical Alzheimer's disease. Brain Imaging Behav, (9)4: 729-736. https://doi.org/10.1007/s11682014-9329-5

Shor, E. - Roelfs, D. J. - Yogev, T. (2013): The strength of family ties: A meta-analysis and metaregression of self-reported social support and mortality. Social Networks, (35)4: 626-638. https://doi.org/10.1016/j.socnet.2013.08.004

Snowdon, D. (2008): Aging with grace: What the nun study teaches us about leading longer, healthier, and more meaningful lives. New York, NY: Bantam Books.

Stern, Y. - Albert, S. - Tang, M. X. - Tsai, W. Y. (1999): Rate of memory decline in AD is related to education and occupation: Cognitive reserve? Neurology, (53)9: 1942-1947. https://doi.org/10.1212/WNL.53.9.1942

Tariska, P. (2002): Kórtünet, vagy kortünet? Mentális zavarok az időskorban. Budapest: Medicina Kiadó.

Urbánné Varga, K. (2005): Zene és Terápia. In: Lindbergerné K. E. (szerk.): Zeneterápia szöveggyűjtemény. Pécs : „Kulcs a Muzsikához” Alapítvány, 99-116.

Valenzuela, M. J. - Sachdev, P. - Wen, W. - Chen, X. - Brodaty, H. (2008): Lifespan mental activity predicts diminished rate of hippocampal atrophy. PLoS One. (7)3: 25-98. https://doi.org/10.1371/journal.pone.0002598

WHO (2017): Global action plan on the public health response to dementia 2017-2025 https://www.who.int/mental_health/neurology/dementia/action_plan_2017_2025/en/ (utolsó letöltés 2021.02.01.)

Wilson, R. S. - Mendes de Leon, C. L. - Barnes, L. L. - Schneider, J. A. - Bienias, J. L. - Evans, D. A. - Bennett, D. A. (2002): Participation in Cognitively Stimulating Activities and Risk of Incident Alzheimer Disease. JAMA( 287)6: 742-748. https://doi.org/10.1001/jama.287.6. 742 
Wilson, R. S. - Scherr, P. A. - Schneider, J. A. - Tang, Y. - Bennett, D. A. (2007): Relation of cognitive activity to risk of developing Alzheimer disease. JAMA (69) 20. https://doi.org/ 10.1212/01.wnl.0000271087.67782.cb

World Health Organization - WHO - 2020 : Dementia. Coppenhagen: WHO http://www.who.int/news-room/fact-sheets/detail/dementia (Utolsó letöltés: 2021.02.01.)

Ryoo, Nayoung et al. (2020): Coping with Dementia in the Middle of the COVID-19 Pandemic. Journal of Korean Medical Science, (35)42: 370-383. http://synapse.koreamed.org/ articles/1146222 (Utolsó letöltés: 2021.02.01.) https://doi.org/10.3346/jkms.2020.35.e383

World Health Organization - WHO - 2021. Wordometer's COVID 19- Hungary. Coppenhagen: WHO. https://www.worldometers.info/coronavirus/country/hungary/ (Utolsó letöltés: 2021.05.08.) 